\title{
Towards a Model of Collaborative Intention: An Empirical Investigation of a Massive Online Open Course (MOOC)
}

\author{
Liana Razmerita \\ Copenhagen Business \\ School \\ lra.msc@cbs.dk
}

\author{
Kathrin Kirchner \\ Berlin School of Economics and \\ Law \\ Kathrin.Kirchner@hwr-berlin.de
}

\author{
Kai Hockerts \\ Chee-Wee Tan \\ Copenhagen Business Copenhagen Business \\ School \\ School \\ kho.msc@cbs.dk \\ ct.digi@cbs.dk
}

\begin{abstract}
Disentangling factors that affect one's intention to collaborate is an important endeavor for management education, especially for globally dispersed groups of students. Drawing on a synthesis of four theories, we advance a model of collaboration intentions that embodies both individual and communal level drivers of individuals' intention to participate in virtual collaboration. The model is validated based on data collected from 2,517 participants in a Massive Online Open Course (MOOC). Results demonstrate that attitudes towards virtual collaboration are predicted by both collaborative outcome expectancy and communal support expectancy. Additionally, we reveal that collaborative outcome expectancy is predicated on individuals' belief about his/her ability to collaborate whereas communal support expectancy is impacted by the individual's perception of communal influence.
\end{abstract}

\section{Introduction}

MOOCs have been a major success story in recent years $[16,17,45]$. However, this euphoria has quickly abated as the limitations of MOOCs become apparent: a lack of social interaction with instructors and/or other students, high dropout rates [27] and demand for a higher level of self-discipline in comparison to traditional education [36].

Group work could play an instrumental role in an online setting like MOOC to cultivate conducive collaborative learning environment, which in turn aids in fostering social learning and interaction. Collaborative learning involves collaborative construction of new knowledge and new problem solving skills through negotiation and sharing of meaning relevant to the task at hand [38].

The rise of MOOCs has propelled interest in how our comprehension of collaborative learning can be applied to dispersed, large-scale, virtual learning communities. For this reason, group work in MOOCs should lead to collaborative learning, social interaction, transfer of skills and peer feedback.
Virtual collaboration in an online setting such as MOOCs presents challenges because students must work in heterogeneous and cross-cultural teams across separate time zones, an activity for which most students will not have experienced before. Compared to face-to-face group work, past studies suggest that students are more inclined to harbor more negative attitudes toward group work in online learning situations as they must contend with discrepancies in languages, time zones and work schedules [30, 37].

Although there is an enduring research stream that embraces diverse perspectives in yielding factors which drive e-collaboration [32, 41], few studies have investigated virtual collaboration at the level of large scale MOOCs with up to thousands of dispersed and heterogeneous learners. In general, collaboration depends on the existence of communal attributes like communication, shared vision and trust, ingredients which are difficult to get hold of in an online setting like MOOCs [29].

This study is hence timely and relevant since higher education is increasingly leaning towards MOOC as a means of extending education to constituents who have been excluded in the past [44]. We submit that autonomous group work among globally dispersed participants in MOOC constitutes a critical component of the online learning paradigm and MOOC pedagogy. This paper therefore aims to achieve the dual objectives below:

- To synthesize extant literature in constructing a research model of collaborative intentions to participate in group work.

- To empirically validate our proposed research model based on data gathered from participants in a MOOC setting.

The paper is structured as follows. First, we review related work and theoretical perspectives that constitute the basis for our research model. Afterwards, we introduce the collaborative intention research model together with testable hypotheses. Next, we present and discuss our findings. Finally, we conclude with the contributions of our study to theory and practice as well as outline limitations and future work. 


\section{Theoretical background}

In constructing the research model underlying this paper, we draw primarily on four established theories about individual and collective intention and behavior, namely Social Cognitive Theory, Theory of Planned Behavior, Social Exchange Theory, and Social Interdependence Theory. These theories were selected as they address behavioral intention (i.e., theory of planned behavior), collective interaction theories (i.e., social interdependence theory and social exchange theory) as well as individual level cognition and learning (i.e., social cognitive theory).

The Social Cognitive Theory (SCT), advanced by Bandura and Walters [11] and later relabeled as the Social Learning Theory [6], emphasized the role of behavioral observation and emulation as drivers of select actions. Social learning theory holds that learning is a cognitive process that occurs in a social context. Accordingly, the SCT was constructed around the following four principal components. First, the SCT posits that learning is based on observing and emulating how others behave (modeling). Next, behavioral models are linked with certain beliefs about the consequences that will typically result from performing the behavior (outcome expectations). Selfefficacy beliefs, on the other hand, affect cognitive functioning through the joint influence of motivational and information processing operations. Finally, SCT predicts that behavior is more likely to be imitated if the person observing shares commonalities with the learner.

The Theory of Planned Behavior (TPB), first proposed by Ajzen [1], has been applied across multiple contexts. To-date, it has been proven to be a relatively robust model in predicting intentions and behavior [13]. The TPB points to four variables as antecedents of an individual's intention formation process: a person's attitude towards a behavior (ATB), perceived subjective norms (PSN), and perceived behavioral control (PBC). PBC, in turn, is delineated into internal and external control [1, 2]. Whereas internal control is usually assessed through a person's self-efficacy [7], external control pertains to the person's beliefs about the social support or opposition available in the environment [34, 46].

The Social Exchange Theory (SET) builds on the work of Thibaut and Kelley [22, 40]. As advocated by the SET, humans are rational agents that decide to engage in a relationship based on cost-benefit analysis. By weighing the costs and benefits of a relationship, we decide whether to engage in social connectivity with others. The SET thus attempts to explain why we interact with others as well as when we seek mutual support in their interactions, relationships and social exchanges. It postulates that people repeat actions for which they have been rewarded in the past.

Social Interdependence Theory (SIT) expands on the SET by unpacking the process through which interdependence among individuals shapes their relational engagement [24, 25]. The SIT has been particularly influential in education research where it has encouraged more cooperative learning [26]. The SIT posits that positive or negative interdependence translates into more or less effective actions, which in turn lead to psychological processes that impact future interaction patterns as well as outcomes at both individual and group levels.

The majority of past studies on group work, which draw extensively on behavioral, cognitive, or motivational theories, tend to accentuate individual factors that shape collaborative learning outcomes. But in doing so, prior research fails to incorporate collective considerations into online communal environments. We therefore endeavor to bridge the aforementioned knowledge gap by unraveling both individual and communal antecedents of collaborative intentions. This leads us to the following research question for the current study: What are the factors influencing collaborative intentions in an online setting like MOOC?

\section{Hypothesis formulation}

In this study, we strive to bridge the knowledge gaps among separate research streams by synthesizing extant literature on collaboration and group work to advance a research model that depicts the focal drivers and psychological mechanisms shaping individuals' collaborative intentions to join virtual group work in MOOCs. Specifically, we posit that collaborative process efficacy and communal influence affect individuals' expectations of collaborative outcome and communal support respectively. Furthermore, we postulate that negative collaborative experience will moderate the relationships between collaborative process efficacy and collaborative outcome expectancy as well as between communal influence and communal support expectancy. In turn, the effects of collaborative outcome expectancy and communal support expectancy on collaborative attitude will be moderated by collaborative technology experience.

\subsection{Collaborative process efficacy}

Collaborative Process Efficacy (CPE), in this study, is defined as the degree to which an individual believes in his/her abilities to facilitate and lead group work. Collaborative process efficacy thus extends the concept 
of individual self-efficacy, as put forth by Bandura [8], to group collaborations. Because collaborative process efficacy denotes an individual's judgment of his/her capabilities to undertake courses of action required to attain designated performance, we anticipate that higher levels of collaborative process efficacy culminate in greater expectations of positive outcomes: H1a: An individual's collaborative process efficacy will positively influence his/her collaborative outcome expectancy towards virtual collaboration.

\subsection{Collaborative outcome expectancy}

Collaborative Outcome Expectancy (COE) refers to the degree to which an individual believes that group work is instrumental in attaining tangible outcomes. As surmised by Bandura [10], the "ability to envision the likely outcomes of prospective actions is another way in which anticipatory mechanisms regulate human motivation and action. People strive to gain anticipated beneficial outcomes and to forestall aversive ones". In this sense, collaborative outcome expectancy signifies the degree to which an individual trusts that group work would improve his/her learning or performance outcome. Both the TPB and the SET hold that a behavior will be favored by individuals whenever its expected benefits outweigh its costs. We therefore hypothesize that an individual's positive expectations about the outcome of collaborative group learning will drive his/her positive attitudes towards such behavior:

H1b: An individual's collaborative outcome expectancy will positively influence his/her collaborative attitude towards virtual collaboration.

\subsection{Communal influence}

Building on the TPB, we conceive Communal Influence (CI) or social norms [3] as a crucial driver of collaborative intentions. We define communal influence as a "person's perception that people who are important to him think he should or should not perform the behavior in question” [19]. In this sense communal influence captures an individual's normative beliefs about the attitudes of peers in their immediate environment [15] in relation to virtual collaboration. We argue that peers' attitudes towards group work will determine the degree to which individuals will expect their peers to play a supportive role in virtual collaboration:

H2a: An individual's communal influence will positively influence his/her communal support expectancy towards virtual collaboration.

\subsection{Communal support expectancy}

Communal Support Expectancy (CSE) refers to an individual's perception of whether their peers will support their engagement in virtual collaborative work. Following on the tenants of the SIT, group behavior and dynamics are key to comprehending virtual collaboration. Peer support can be described by means of factors such as active participation in virtual collaboration, communication among group members, as well as trust and cohesion among collaborators [21]. Willingness to engage in open communication and collaboration within a group is influenced by commonalities among team members, especially when familiarity among members is present [23]. Consistent with SCT, we hypothesize that individuals' positive outcome expectancy regarding communal support will be associated with his/her positive attitude towards virtual collaboration:

H2b: An individual's communal support expectancy will positively influence his/her attitude towards virtual collaboration.

\subsection{Collaborative attitude}

Attitude toward a behavior is the level to which execution of the behavior is positively or negatively assessed. According to the TPB, one's attitude towards a behavior is regulated by an arrangement of behavioral beliefs associating a behavior with specific outcomes [3, 19]. The notion of outcome expectancy originates from the Expectancy Value Model [5], which spawns the SCT. Evaluation of a particular outcome influences one's attitude in direct proportion to our subjective assessment of whether or not a behavior produces desired or unwanted outcome [9]. It links beliefs, attitudes, and opinions with expectations about behavioral outcomes.

In this study, we treat Collaborative Attitude (CA) as the sum of positive and negative feelings, beliefs, and opinions about virtual collaboration, which in turn result in either approval or disapproval of such behavior. Research on e-learning technology showed that users possessed higher usage intention when they view it with a more positive attitude [31]:

H3: An individual's collaborative attitude will positively influence his/her intention to engage in virtual collaboration.

\subsection{Negative collaborative experience}

While group work has numerous benefits, it also has its drawbacks, especially in online contexts. Negative Collaborative Experience (NCE) is pivotal in a collaborative environment, more so for online settings such as MOOCs where participants are dispersed all over the globe. The group building process is time 
consuming, and scheduling the collaboration is not an easy task, especially if individuals are not acquainted with one another and are distributed in space and time [37].

The SCT suggests that people draw on past experiences as frames of reference for future actions, forming generalized mental models based on previous occurrences [9]. While such cognitive models offer invaluable heuristics, they can also be detrimental by reinforcing negative stereotypes.

For example, as a consequence of negative collaborative experience, students may resist group approaches to distance learning. Students may treat stipulated requirements to engage in virtual collaboration as limitations on their self-determination, being too time consuming and tedious, or permitting free-riders and underachievers to benefit unfairly from their own contributions [37]. Overgeneralization from previous negative experiences can lead individuals to reject meritocratic behavior, a trend known as cognitive distortion [18]. As noted by Ashcraft and Treadwell [4], students "often dislike group work because the learner had earlier negative group experiences where they felt responsible for completing it all or most of the assignment adequately, and without the aid of group members".

Prior research has identified social loafing, the absence of group coordination and commitment as well as the lack of time and trust as potential challenges individuals may encounter in collaborative environments [33]. Such negative experiences could be magnified in online settings due to estranged communication channels and the need for adjustment to a foreign learning environment [4]. In this study, we define negative collaborative experience as the extent to which an individual has encountered problems in previous group work such as social loafing, lack of trust and coordination [33][28]. Because negative collaborative experience will erode an individual's confidence in virtual collaborations, we expect that it will attenuate the relationships between collaborative process efficacy and collaborative outcome expectancy as well as between communal influence and communal support expectancy:

H4a: An individual's negative collaborative experiences will attenuate the effect of collaborative process efficacy on collaborative outcome expectancy.

H4b: An individual's negative collaborative experiences will attenuate the effect of communal influence on communal support expectancy.

\subsection{Collaborative technology experience}

Past studies have demonstrated how prior experiences with Information Technology (IT) usage can positively affect individuals' attitudes towards future IT use [14] or e-learning [31]. Through a review of extant literature, we uncover that students' learning experiences depend, to a large extent on their knowledge and proficiency of collaborative technology [43]. Just as negative experiences with group work can produce adverse effects, positive experience with collaborative technology can culminate in optimistic outcome expectations. Particularly, we propose that collaborative technology experience will positively moderate the effect of collaborative outcome expectancy on collaborative attitude. Moreover, we posit that collaborative technology experience will strengthen the relationship between communal support expectancy and collaborative attitude because communal support can be garnered more effectively through leveraging on collaborative technology:

H5a: An individual's collaborative technology experience will reinforce the effect of collaborative outcome expectancy on collaborative attitude.

H5b: An individual's collaborative technology experience will reinforce the effect of communal support expectancy on collaborative attitude.

\section{Methodology}

Hypothesized relationships were validated via a survey questionnaire administered on respondents recruited from the student population enrolled in a MOOC offered by a large Scandinavian business school on the Coursera website. According to course objectives, students are expected to form groups for cocreating innovative ideas and formulating business plans but they could also work individually on their business plan. In total, 28,967 students signed up for the course in April 2015. Nevertheless, approximately $40 \%$ of the students, who signed up for the course, never even visited the course website once. For this reason, it is natural that these dormant students will not have the opportunity to participate in the online survey. A total of 2,517 completed responses were obtained at the outset of the course, translating into an estimated response rate of $14.48 \%$.

At the beginning of the course, students were instructed to form self-organized groups. These groups were then required to: (1) find a social problem worthy of investigation; (2) spot an opportunity for how to address the problem, and; (3) compose a business plan. Although group work was strongly recommended, students were also permitted to work on their own.

With the exception of covariate control variables (e.g., age, gender and nationality), multiple-item scales were employed to measure the latent variables. Each scale item utilized a 5-point Likert-scale format 
ranging from 1 - "strongly disagree" to 5 - "strongly agree”. Measurement items for the four latent variables of the TPB and collaborative intentions were newly developed in accordance with standard psychometric procedures. Conversely, measures for factors influencing group work and negative experiences were extracted from prior research and adapted for this study [33, 42]. The complete list of measurement items is summarized in Table 1 below.

\begin{tabular}{|c|c|c|c|c|c|c|c|}
\hline \multicolumn{8}{|c|}{ Table 1. List of Measurement Items } \\
\hline Construct & Definition & Measure & $\begin{array}{c}\text { Mean } \\
\text { (Std Dev) }\end{array}$ & $\begin{array}{l}\text { Factorial } \\
\text { Loading }\end{array}$ & $\begin{array}{c}\text { Average } \\
\text { Variance } \\
\text { Extracted } \\
\text { (AVE) } \\
{[>0.50]}\end{array}$ & $\begin{array}{c}\text { Composite } \\
\text { Reliability } \\
{[>0.70]}\end{array}$ & $\begin{array}{c}\text { Cronbach's } \\
\text { Alpha }(\alpha) \\
{[>0.70]}\end{array}$ \\
\hline \multirow[t]{3}{*}{$\begin{array}{l}\text { Communal } \\
\text { Influence } \\
\text { (COI) }\end{array}$} & \multirow{3}{*}{$\begin{array}{l}\text { Degree to which an } \\
\text { individual believes } \\
\text { that his/her peers } \\
\text { think he/she should } \\
\text { engage in virtual } \\
\text { collaboration [19] }\end{array}$} & $\begin{array}{l}\text { Most of my peers would expect me } \\
\text { to contribute towards optional group } \\
\text { work. }\end{array}$ & $3.74(0.72)$ & 0.73 & \multirow{3}{*}{0.55} & \multirow{3}{*}{0.79} & \multirow{3}{*}{0.60} \\
\hline & & $\begin{array}{l}\text { Most of my peers would contribute } \\
\text { towards optional group work. }\end{array}$ & $3.59(0.73)$ & 0.81 & & & \\
\hline & & $\begin{array}{l}\text { Most of my peers would argue that } \\
\text { group work enhances their } \\
\text { effectiveness. }\end{array}$ & $3.52(0.81)$ & 0.69 & & & \\
\hline \multirow{4}{*}{$\begin{array}{l}\text { Communal } \\
\text { Support } \\
\text { Expectancy } \\
\text { (CSE) }\end{array}$} & \multirow{4}{*}{$\begin{array}{l}\text { Degree to which an } \\
\text { individual is } \\
\text { convinced that other } \\
\text { group members will } \\
\text { support him/her } \\
\text { during group work }\end{array}$} & $\begin{array}{l}\text { I am sure that my group members } \\
\text { would support me. }\end{array}$ & $3.84(0.63)$ & 0.84 & \multirow{4}{*}{0.67} & \multirow{4}{*}{0.89} & \multirow{4}{*}{0.84} \\
\hline & & $\begin{array}{l}\text { People in my group would back me } \\
\text { up. }\end{array}$ & $3.83(0.64)$ & 0.83 & & & \\
\hline & & I would receive help from my group. & $3.96(0.56)$ & 0.86 & & & \\
\hline & & $\begin{array}{l}\text { I could count on my group members } \\
\text { to help me when I face difficulties. }\end{array}$ & $3.85(0.69)$ & 0.74 & & & \\
\hline \multirow{4}{*}{$\begin{array}{l}\text { Collaborative } \\
\text { Process } \\
\text { Efficacy (CPE) }\end{array}$} & \multirow{4}{*}{$\begin{array}{l}\text { Degree to which an } \\
\text { individual is } \\
\text { confident in his/her } \\
\text { ability to work in } \\
\text { groups }\end{array}$} & I am good at group work. & $4.01(0.63)$ & 0.83 & \multirow{4}{*}{0.62} & \multirow{4}{*}{0.87} & \multirow{4}{*}{0.80} \\
\hline & & $\begin{array}{l}\text { If there was conflict in my group } \\
\text { work I would be able to solve it } \\
\text { amicably. }\end{array}$ & $4.01(0.63)$ & 0.73 & & & \\
\hline & & $\begin{array}{l}\text { I would be able to motivate group } \\
\text { members to contribute towards the } \\
\text { group effort. }\end{array}$ & $4.01(0.63)$ & 0.78 & & & \\
\hline & & $\begin{array}{l}\text { I possess the skills required for group } \\
\text { work. }\end{array}$ & $4.01(0.62)$ & 0.81 & & & \\
\hline \multirow{3}{*}{$\begin{array}{l}\text { Collaborative } \\
\text { Outcome } \\
\text { Expectancy } \\
\text { (COE) }\end{array}$} & \multirow{3}{*}{$\begin{array}{l}\text { Degree to which an } \\
\text { individual believes } \\
\text { that group work is } \\
\text { instrumental in } \\
\text { achieving tangible } \\
\text { outcomes }\end{array}$} & $\begin{array}{l}\text { I have usually enjoyed group work } \\
\text { collaboration. }\end{array}$ & $3.96(0.76)$ & 0.82 & \multirow{3}{*}{0.65} & \multirow{3}{*}{0.85} & \multirow{3}{*}{0.73} \\
\hline & & $\begin{array}{l}\text { Group work collaboration has } \\
\text { enabled me to learn new things. }\end{array}$ & $4.20(0.70)$ & 0.78 & & & \\
\hline & & $\begin{array}{l}\text { Group work collaboration has given } \\
\text { me new perspectives on the topic I } \\
\text { have worked on. }\end{array}$ & $4.13(0.69)$ & 0.81 & & & \\
\hline \multirow{6}{*}{$\begin{array}{l}\text { Collaborative } \\
\text { Attitude } \\
\text { (ATT) }\end{array}$} & \multirow{6}{*}{$\begin{array}{l}\text { An individual's } \\
\text { positive or negative } \\
\text { feelings about } \\
\text { performing the } \\
\text { target behavior [20] }\end{array}$} & Group work is effective. & $4.06(0.74)$ & 0.72 & \multirow{6}{*}{0.62} & \multirow{6}{*}{0.91} & \multirow{6}{*}{0.88} \\
\hline & & Group work is important & $4.31(0.65)$ & 0.81 & & & \\
\hline & & Group work is relevant & $4.25(0.65)$ & 0.81 & & & \\
\hline & & Group work is unnecessary & $4.21(0.76)$ & 0.78 & & & \\
\hline & & Group work is irrelevant & $4.26(0.72)$ & 0.80 & & & \\
\hline & & Group work is a waste of time & $4.26(0.76)$ & 0.81 & & & \\
\hline \multirow{4}{*}{$\begin{array}{l}\text { Collaborative } \\
\text { Intentions } \\
\text { (INT) }\end{array}$} & \multirow{4}{*}{$\begin{array}{l}\text { An indication of an } \\
\text { individual's readiness } \\
\text { to perform a given } \\
\text { behavior [1] }\end{array}$} & $\begin{array}{l}\text { I intend to join the optional group } \\
\text { work in this MOOC. }\end{array}$ & $3.76(0.73)$ & 0.83 & \multirow{4}{*}{0.66} & \multirow{4}{*}{0.90} & \multirow{4}{*}{0.87} \\
\hline & & $\begin{array}{l}\text { I intend to work on my own without } \\
\text { participating in the optional group } \\
\text { work. }\end{array}$ & $3.50(0.86)$ & 0.77 & & & \\
\hline & & \begin{tabular}{|l|} 
I am planning to take an active part \\
in the optional group work.
\end{tabular} & $3.69(0.75)$ & 0.86 & & & \\
\hline & & I do not expect to participate much in & $3.51(0.83)$ & 0.83 & & & \\
\hline
\end{tabular}




\begin{tabular}{|c|c|c|c|c|c|c|c|}
\hline & & $\begin{array}{l}\text { the optional group work in this } \\
\text { MOOC. }\end{array}$ & & & & & \\
\hline & & $\begin{array}{l}\text { I expect to spend considerable time } \\
\text { on optional group work in this } \\
\text { MOOC. }\end{array}$ & $3.39(0.82)$ & 0.76 & & & \\
\hline \multirow{2}{*}{$\begin{array}{l}\text { Collaborative } \\
\text { Technology } \\
\text { Experience } \\
\text { (CTE) }\end{array}$} & \multirow{2}{*}{$\begin{array}{l}\text { Degree to which an } \\
\text { individual has prior } \\
\text { experience with } \\
\text { collaborative } \\
\text { technology for } \\
\text { facilitating group } \\
\text { work }\end{array}$} & $\begin{array}{l}\text { I have used online tools as part of my } \\
\text { previous group work. }\end{array}$ & $3.58(1.16)$ & 0.75 & \multirow{2}{*}{0.74} & \multirow{2}{*}{0.85} & \multirow{2}{*}{0.70} \\
\hline & & $\begin{array}{l}\text { E-collaboration tools are very useful } \\
\text { to support group work. }\end{array}$ & $4.01(0.76)$ & 0.96 & & & \\
\hline \multirow{5}{*}{$\begin{array}{l}\text { Negative } \\
\text { Collaborative } \\
\text { Experience } \\
\text { (NCE) }\end{array}$} & \multirow{5}{*}{$\begin{array}{l}\text { Degree to which an } \\
\text { individual perceives } \\
\text { difficulties in group } \\
\text { work based on } \\
\text { his/her prior } \\
\text { experience(s) }\end{array}$} & $\begin{array}{l}\text { I have experienced lack of } \\
\text { coordination in previous group work. }\end{array}$ & $3.51(0.95)$ & 0.70 & \multirow{5}{*}{0.50} & \multirow{5}{*}{0.83} & \multirow{5}{*}{0.74} \\
\hline & & $\begin{array}{l}\text { I have experienced lack of trust } \\
\text { among team members in previous } \\
\text { group work. }\end{array}$ & $3.06(1.03)$ & 0.67 & & & \\
\hline & & $\begin{array}{l}\text { I have experienced difficulties due to } \\
\text { different educational backgrounds in } \\
\text { previous group work. }\end{array}$ & $2.96(1.04)$ & 0.73 & & & \\
\hline & & $\begin{array}{l}\text { I have experienced difficulties due to } \\
\text { different levels of knowledge in } \\
\text { previous group work. }\end{array}$ & $3.33(0.98)$ & 0.77 & & & \\
\hline & & $\begin{array}{l}\text { I have experienced difficulties due to } \\
\text { lack of commitment in previous } \\
\text { group work. }\end{array}$ & $3.54(0.96)$ & 0.63 & & & \\
\hline
\end{tabular}

\section{Data Analysis}

Of the 2,517 respondents, $54.7 \%$ were female and the average age was 35 years old. The majority of respondents possessed either a master $(43.7 \%)$ or a bachelor (40.1\%) degree. Descriptive statistics reveal that $76.5 \%$ of respondents possessed extensive experience with group work whereas $67.7 \%$ had been exposed to e-collaboration tools before, which include social networks (e.g., Google Hangout, Facebook and Podio). Country-wise, the sample consists of respondents from 120 countries with the five most represented nationalities being the United States (15.7\%), India (10.5\%), Mexico (4.3\%), Brazil (4.2\%) and Spain (2.8\%).

Partial Least Squares (PLS) analysis was employed to validate the measurement and structural properties of our research model. PLS analysis is preferred because it tests the psychometric properties of the measurement items (i.e., the measurement model) while simultaneously, analyzing the direction and strength of hypothesized relationships (i.e., the structural model).

The test of the measurement model involves the estimation of internal consistency as well as the convergent and discriminant validity of the measurement items included in our survey instrument.

Because reflective items supposedly capture the effects of the construct under scrutiny, internal consistency can be assessed through standard estimates of Cronbach's alpha, composite reliability and the Average Variance Extracted (AVE). After dropping one measurement item for the construct of collaborative technology experience due to low factorial loading, it is deducible from Table 1 that all latent constructs exceed prescribed thresholds. Furthermore, factorial loadings of measurement items on their respective latent constructs are greater than 0.70 . Together, these indicators support convergent validity.

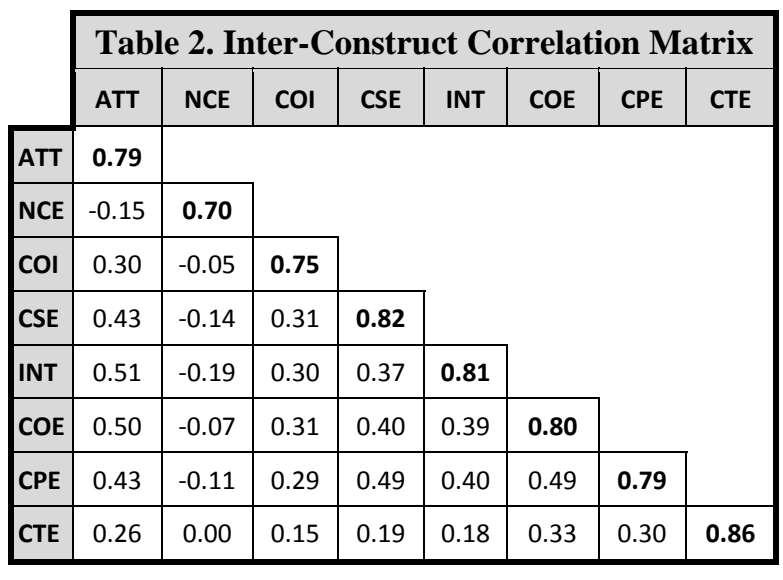

Note: Square root of AVE displayed on diagonals.

To ascertain discriminant validity, the square root of the AVE for each construct was compared against its correlations with other constructs. For the criterion of discriminant validity to hold, the square root of the 
AVE for each construct should be greater than its correlations with any other construct [39]. Based on the inter-construct correlation matrix generated from PLS (see Table 2), all constructs display sufficient discriminant validity.

Results from the PLS analysis of the structural model, including path coefficients and their statistical significance, are illustrated in Figure 1. Standard errors were computed via a bootstrapping procedure with 500 re-samples. From our data analysis, all hypothesized relationships were substantiated by the empirical evidence. As hypothesized, collaborative process efficacy and communal influence exert positive and significant effects on collaborative outcome expectancy $(\beta=0.483 ; p<.001)$ and communal support expectancy $(\beta=0.301 ; p<.001)$ respectively, explaining $23.8 \%$ and $11.4 \%$ of the variance in the two constructs.

Hypotheses 1a and 2a are hence corroborated. In turn, collaborative outcome expectancy $(\beta=0.365 ; p<$ $.001)$ and communal support expectancy $(\beta=0.265 ; p$ $<.001$ ) exhibit significant and positive impact on collaborative attitude, explaining 32.4\% of the variance in the latter. Hypotheses $1 \mathrm{~b}$ and $2 \mathrm{~b}$ are substantiated.

Collaborative attitude in turn affects collaborative intention positively ( $\beta=0.506 ; p<.001$ ), explaining $25.6 \%$ of the variance and lending support to Hypothesis 3.

Although negative collaborative experience attenuates the positive effect of collaborative process efficacy on collaborative outcome expectancy $(\beta=-$ $0.051 ; p<.01$ ) as anticipated, its reinforcement of the relationship between communal influence and communal support expectancy $(\beta=0.069 ; p<.001)$ runs contrary to our expectation. Hypothesis $4 \mathrm{a}$ is thus supported but not Hypothesis 4b.

Likewise, even though collaborative technology experience reinforces the positive impact of collaborative outcome expectancy on collaborative attitude $(\beta=0.067 ; p<.05)$ as posited, it does not influence the relationship between communal support expectancy and collaborative attitude $(\beta=-0.028 ; p>$ $.05)$. This lends credibility to Hypothesis $5 \mathrm{a}$, but not Hypothesis 5b.

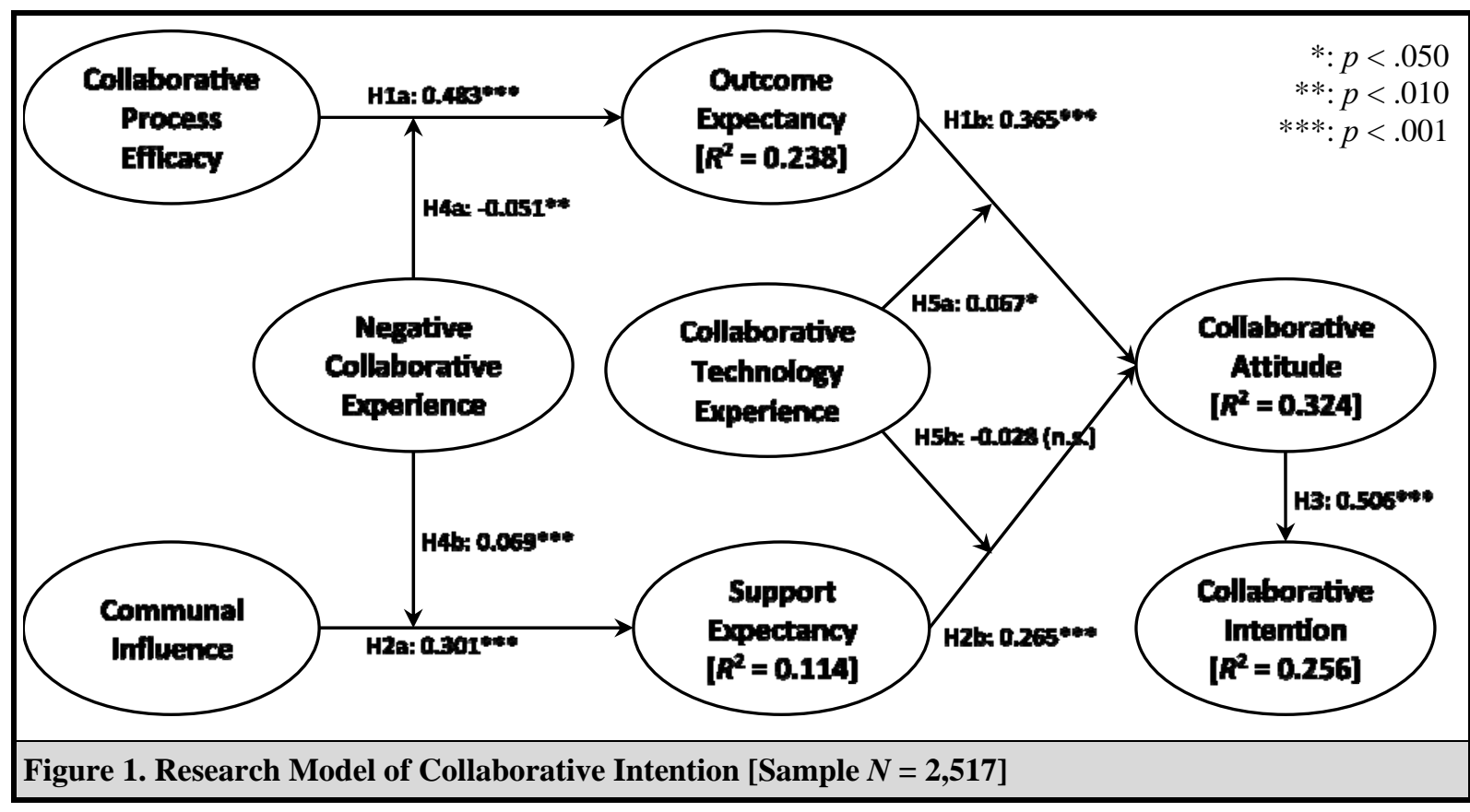

Following procedures advocated by [39], we employed the pseudo- $F$ test to assess the impact of dropping either collaborative outcome expectancy or communal support expectancy on collaborative attitude. The effect size of $f^{2}$ was estimated as $\left(R^{2}\right.$ full $R_{\text {excluded }}^{2} /\left(1-R_{\text {full }}^{2}\right.$ ), and the pseudo-F statistic was computed by multiplying $f^{2}$ by $(n-k-1)$ where $n$ is the sample size and $k$ is the number of independent constructs. As indicated in Table 3, excluding either collaborative outcome expectancy or communal support expectancy from the model contributes to a significant decrease in variance for collaborative attitude. Additionally, we adhered to the guidelines prescribed by [12] and performed mediation analysis to determine whether collaborative outcome expectancy, communal support expectancy, and collaborative attitude act as full or partial mediators. Table 4 summarizes the results from our mediation analyses. 


\begin{tabular}{|l|c|c|c|c|}
\hline \multicolumn{5}{|c|}{ Table 3: Pseudo-F Test [Sample $N=2,517]$} \\
\hline Comparison & $\boldsymbol{R}_{\text {excluded }}^{2}$ & $\boldsymbol{R}_{\text {full }}^{2}$ & $\boldsymbol{f}^{2}$ value & $P_{\text {seudo-F Statistic }}$ \\
\hline COE Excluded & 0.262 & 0.324 & 0.092 & $F_{(1,2514)}=231.29 * * *$ \\
\hline CSE Excluded & 0.288 & 0.324 & 0.053 & $F_{(1,2514)}=133.24 * * *$ \\
\hline
\end{tabular}

As pointed out by [12], when the path from independent variable (IV) to the mediator as well as the path from the mediator to the dependent variable (DV) are controlled, the path coefficient from IV to DV should decrease in both magnitude and significance. If the path coefficient between IV and DV becomes nonsignificant, we can interpret the mediating effect as a full mediation. Otherwise, it should be interpreted as a partial mediation. From Table 4, it is evident that the impact of collaborative process efficacy and communal influence on collaborative attitude are partially mediated by collaborative outcome expectancy and communal support expectancy respectively. Similarly, collaborative attitude partially mediates the effects of collaborative outcome expectancy and communal support expectancy on collaborative intention.

\begin{tabular}{|c|c|c|}
\hline \multicolumn{3}{|c|}{ Table 4: Mediation Analysis } \\
\hline Relationship & Independent Paths & Full Model \\
\hline \multicolumn{3}{|c|}{ IV: Collaborative Process Efficacy } \\
\hline $\mathrm{CPE} \rightarrow \mathrm{COE}$ & $0.485^{* * *}$ & $0.483 * * *$ \\
\hline $\mathrm{COE} \rightarrow \mathrm{ATT}$ & $0.498 * * *$ & $0.365 * * *$ \\
\hline $\mathrm{CPE} \rightarrow \mathrm{ATT}$ & $0.429 * * *$ & $0.148 * * *$ \\
\hline \multicolumn{3}{|c|}{ Partial Mediation } \\
\hline \multicolumn{3}{|c|}{ IV: Communal Influence } \\
\hline $\mathrm{COI} \rightarrow \mathrm{CSE}$ & $0.308 * * *$ & $0.301 * * *$ \\
\hline $\mathrm{CSE} \rightarrow \mathrm{ATT}$ & $0.434^{* * *}$ & $0.265^{* * *}$ \\
\hline $\mathrm{COI} \rightarrow \mathrm{ATT}$ & $0.316^{* * *}$ & $0.112^{* * *}$ \\
\hline \multicolumn{3}{|c|}{ Partial Mediation } \\
\hline \multicolumn{3}{|c|}{ IV: Collaborative Attitude } \\
\hline $\mathrm{COE} \rightarrow \mathrm{ATT}$ & $0.497 * * *$ & $0.365^{* * *}$ \\
\hline $\mathrm{ATT} \rightarrow \mathrm{INT}$ & $0.506^{* * *}$ & $0.506^{* * *}$ \\
\hline $\mathrm{COE} \rightarrow \mathrm{INT}$ & $0.398 * * *$ & $0.191 * * *$ \\
\hline \multicolumn{3}{|c|}{ Partial Mediation } \\
\hline $\mathrm{CSE} \rightarrow \mathrm{ATT}$ & $0.431^{* * *}$ & $0.265^{* * *}$ \\
\hline $\mathrm{ATT} \rightarrow \mathrm{INT}$ & $0.506 * * *$ & $0.506 * * *$ \\
\hline $\mathrm{CSE} \rightarrow \mathrm{INT}$ & $0.375^{* * *}$ & $0.190 * * *$ \\
\hline \multicolumn{3}{|c|}{ Partial Mediation } \\
\hline
\end{tabular}

\section{Discussion}

There is a limited comprehension of the factors shaping collaborative intentions in online settings, especially with regards to how attitudes towards collaboration as well as previous experience with group work and collaborative technologies affect individuals' intentions to engage in virtual collaborations. From our review of extant literature, we discover a dearth of research that sheds light on how collaboration could be induced in online learning environments.

To this end, this study disentangles the focal factors that contribute to collaborative intentions to engage in group work within online settings from both individual and communal standpoints. Specifically, we advance a model of collaboration that integrates both individuals' perceived ability to work in group (i.e., collaborative process efficacy) as well as their perceived peer influence related to group work (i.e., communal influence).

On one hand, individuals' perceived ability to work in groups has a significant impact on their perceived benefits of collaboration (i.e., outcome expectancy), which in turn dictates their collaborative attitude and the collaborative intention. As expected, negative collaborative experience attenuates the relationship between collaborative process efficacy and collaborative outcome expectancy whereas collaborative technology experience reinforces the relationship between collaborative outcome expectancy and collaboration attitude.

Conversely, perceptions of peer influence related to group work (i.e., communal influence) has a significant and positive effect on an individual's belief that others will support him in group work (i.e., communal support expectancy), which in turn drives his/her collaborative attitude and intentions. Contrary to our anticipation, negative collaborative experience reinforces the relationship between communal influence and the communal support. Moreover, we found that collaborative technology experience has no significant influence on the relationship between communal support expectancy and collaborative attitude.

From above, it is apparent that this study departs from prior research by delivering a holistic view of the drivers of collaboration in online settings. Our proposed research model contributes to a more comprehensive understanding of the focal individual and communal (social) factors that play a significant role in one's decision to engage in virtual collaboration within online settings. Furthermore, even though we have validated our research model in a MOOC setting, there is no reason for us to doubt that our findings cannot be extrapolated to other online learning environments. An intricate understanding of the factors driving one's motivation to collaborate virtually will be invaluable in guiding instructors in the design of group work assignments and pedagogical interventions to 
increase communal engagement and interaction while mitigating previous negative experiences.

\section{Limitations and future work}

While our research model has accounted for psychological mechanisms and focal constructs (factors) driving individuals' collaborative intentions, we did not control for the impact of demographics in this study. Future work could investigate the effects of gender, educational background or digital literacy on collaborative intentions. An in-depth appreciation of the factors driving collaborative intentions would aid in the design of pedagogical interventions to increase communal engagement and interaction while mitigating previous negative experiences. MOOC instructors have to stay vigilant against the spread of negative communal influence through "emotional contagion” [35] because such influence could be hard to overcome once it is entrenched.

It is enticing to presume that group work will improve engagement, increase learning, and augment students' evaluation of the course. Nevertheless, future research needs to evaluate whether the incorporation of group work into online settings truly converts into discernible improvements in students' academic performances and satisfaction.

\section{References}

[1] Ajzen, I., "The theory of planned behavior", Organizational Behavior and Human Decision Processes 50(2), 1991, pp. 179-211.

[2] Ajzen, I., "Perceived behavioral control, self-efficacy, locus of control, and the theory of planned behavior", Journal of Applied Social Psychology 32(4), 2002, pp. 665683.

[3] Ajzen, I., “The theory of planned behaviour: Reactions and reflections”, Psychology and Health 26(9), 2011, pp. 113-1127.

[4] Ashcraft, D., and T. Treadwell, "The social psychology of online collaborative learning: The good, the bad, and the awkward”, Computer-supported collaborative learning: Best practices and principles for instructors, 2007, pp. 114-139.

[5] Atkinson, J.W., "Motivational determinants of risk-taking behavior”, Psychological Review 64(6), 1957, pp. 359-372.

[6] Bandura, A., Social learning theory, Englewood Cliffs, 1977.

[7] Bandura, A., "Self-efficacy: toward a unifying theory of behavioral change.”, Psychological review 84(2), 1977, pp. 191-215.
[8] Bandura, A., "Self-efficacy: Toward a unifying theory of behavioral change”, Psychological Review 84(2), 1977, pp. 191-215.

[9] Bandura, A., Social foundations of thought and action: A social cognitive theory, 1986.

[10] Bandura, A., "Human agency in social cognitive theory”, American Psychologist 44(9), 1989, pp. 1175-1184.

[11] Bandura, A., and R.H. Walters, Social learning and personality development, Holt, Rinehart and Winston, New York, 1963.

[12] Baron, R.M., and D.A. Kenny, "The ModeratorMediator Variable Distinction in Social Psychological Research: Conceptual, Strategic, and Statistical Considerations", Journal of Personality and Social Psychology 51(6), 1986, pp. 1173-1182.

[13] Beck, L., and I. Ajzen, "Predicting dishonest actions using the theory of planned behavior", Journal of Research in Personality 25(3), 1991, pp. 285-301.

[14] Bhattacherjee, A., and G. Premkumar, "Understanding changes in belief and attitude toward information technology usage: a theoretical model and longitudinal test”, MIS quarterly 28(2), 2004, pp. 229-254.

[15] Cialdini, R.B., R.R. Reno, and C.A. Kallgren, "A focus theory of normative conduct: Recycling the concept of norms to reduce littering in public places.”, Journal of Personality and Social Psychology 58(6), 1990, pp. 1015-1026.

[16] Clarke, T., "The advance of the MOOCs (massive open online courses): The impending globalisation of business education?”, Education + Training 55(4), 2013, pp. 403-413.

[17] Daniel, J., "Making Sense of MOOCs: Musings in a Maze of Myth, Paradox and Possibility.”, Journal of Interactive Media in Education Perspectiv, 2012, pp. 36.

[18] Dawes, R.M., “Cognitive distortion”, Psychological Reports 14, 1964, 443-459.

[19] Fishbein, M., and I. Ajzen, "Belief, Attitude, Intention, and Behavior, An Introduction to Theory and Research", Belief, Attitude, Intention, and Behavior, An Introduction to Theory and Research(February), 1975, pp. 578.

[20] Fishbein, M., and I. Ajzen, Belief, attitude, intention, and behavior: an introduction to theory and research, Addison-Wesley Pub. Co, 1975.

[21] Greenlee, B.J., and Z. Karanxha, “A study of group dynamics in educational leadership cohort and non-cohort groups", Journal of Research on Leadership Education 5(11), 2010, pp. 357-382.

[22] Homans, G.C., Human behavior: Its elementary forms, 
1961.

[23] Janssen, J., G. Erkens, P.A. Kirschner, and G. Kanselaar, "Influence of group member familiarity on online collaborative learning", Computers in Human Behavior 25(1), 2009, pp. 161-170.

[24] Johnson, D.W., The social psychology of education, 1970.

[25] Johnson, D.W., and R.T. Johnson, Cooperation and competition: Theory and research, Interaction Book Company, 1989.

[26] Johnson, D.W., and R.T. Johnson, "An Educational Psychology Success Story: Social Interdependence Theory and Cooperative Learning”, Educational Researcher 38(5), 2009, pp. 365-379.

[27] Jordan, K., "Initial trends in enrolment and completion of massive open online courses”, International Review of Research in Open and Distance Learning 15(1), 2014, pp. 133-160.

[28] Latane, B., K. Williams, and S. Harkins, "Many hands make light the work: The causes and consequences of social loafing”, Journal of personality and social psychology 37(6), 1979, pp. 822.

[29] Mattessich, P.W., and B.R. Monsey, Collaboration: what makes it work. A review of research literature on factors influencing successful collaboration., ERIC, 1992.

[30] Ocker, R.J., and G.J. Yaverbaum, "Collaborative Learning Environments: Exploring Student Attitudes and Satisfaction in Face-to-Face and Asynchronous Computer Conferencing Settings”, Journal of Interactive Learning Research 12(4), 2001, pp. 427-448.

[31] Park, S.Y., "An Analysis of the Technology Acceptance Model in Understanding University Students' Behavioral Intention to Use e-Learning”, Journal of Educational Technology \& Society 12(4), 2009, pp. 150-162.

[32] Rafferty, P.D., “Group Work in the MBA Classroom: Improving Pedagogical Practice and Maximizing Positive Outcomes With Part-Time MBA Students ", Journal of Management Education 37(5), 2013, pp. 623-650.

[33] Razmerita, L., and K. Kirchner, "Collaboration and ECollaboration: A Study of Factors that Influence Perceived Students' Group Performance”, 48th Hawaii International Conference on System Sciences (HICSS), (2015).

[34] Sarason, I.G., H.M. Levine, R.B. Basham, and B.R. Sarason, "Assessing social support: The Social Support Questionnaire.”, Journal of Personality and Social Psychology 44(1), 1983, pp. 127-139.

[35] Schaefer, R.A.B., and M.E. Palanski, "Emotional Contagion at Work An In-Class Experiential Activity”,
Journal of Management Education 38(4), 2014, pp. 533-559.

[36] Sinha, T., N. Li, P. Jermann, and P. Dillenbourg, "Capturing 'attrition intensifying' structural traits from didactic interaction sequences of MOOC learners", EMNLP 2014 Workshop on Modeling Large Scale Social Interaction in Massively Open Online Courses, (2014).

[37] Smith, G.G., C. Sorensen, A. Gump, A.J. Heindel, M. Caris, and C.D. Martinez, "Overcoming student resistance to group work: Online versus face-to-face”, The Internet and Higher Education 14(2), 2011, pp. 121-128.

[38] Stahl, G., T. Koschmann, and D. Suthers, “Computersupported Collaborative Learning: An Historical Perspective", In Cambridge handbook of the learning sciences. 2006, 409-426.

[39] Tan, C.W., I. Benbasat, and R. Cenfetelli, "IT-Mediated Customer Service Content and Delivery in Electronic Governments: An Empirical Investigation of the Antecedents of Service Quality”, MIS Quarterly 37(1), 2013, pp. 77-109.

[40] Thibaut, J.W., and H.H. Kelley, The Social Psychology of Groups, 1959.

[41] Turel, O., and Y. (Jenny) Zhang, "Should I e-collaborate with this group? A multilevel model of usage intentions", Information \& Management 48(1), 2011, pp. 62-68.

[42] Turel, O., and Y. (Jenny) Zhang, "Should I e-collaborate with this group? A multilevel model of usage intentions", Information \& Management 48(1), 2011, pp. 62-68.

[43] Venkatesh, V., A.M. Croteau, and J. Rabah, "Perceptions of Effectiveness of Instructional Uses of Technology in Higher Education in an Era of Web 2.0”, 2014 47th Hawaii International Conference on System Sciences, 2014, 110-119.

[44] Yuan, L., and S. Powell, "MOOCs and Open Education: Implications for Higher Education”, Cetis, 2013, pp. 19.

[45] Zhou, M., “Chinese university students' acceptance of MOOCs: A self-determination perspective”, Computers \& Education2, 2016, pp. 194-203.

[46] Zimet, G.D., N.W. Dahlem, S.G. Zimet, and G.K. Farley, "The Multidimensional Scale of Perceived Social Support”, Journal of Personality Assessment 52(1), 1988, pp. 30-41. 